\title{
ON DISCRETENESS OF SPECTRUM OF A SECOND ORDER FUNCTIONAL DIFFERENTIAL OPERATOR
}

\author{
(C) S. M. Labovskiy \\ Plekhanov Russian University of Economics \\ 36, Stremyanny lane, Moscow 117997, Russian Federation \\ E-mail: labovski@gmail.com
}

Abstract. Necessary and sufficient conditions for discreteness of spectrum for the singular second order functional differential operator of the form

$$
\frac{1}{\rho(x)}\left(-\left(p(x) u^{\prime}\right)^{\prime}+q(x) u-\int_{a}^{b} u(s) r(x, d s)\right), x \in(a, b),-\infty \leq a<b \leq \infty
$$

are obtained.

Keywords: discreteness of spectrum; functional differential operator

\section{The main results.}

Let $\mathcal{L}$ be the functional differential operator defined by

$$
\mathcal{L} u(x):=\frac{1}{\rho(x)}\left(\left(-p(x) u^{\prime}\right)^{\prime}+q(x) u-\int_{a}^{b} u(s) r(x, d s)\right), x \in(a, b),
$$

$-\infty \leq a<b \leq \infty$. Let $I:=(a, b)$. Recall that the spectrum of an operator $A$ acting in a Hilbert space $H$ is discrete if it consists only of eigenvalues of finite multiplicity (see, for example, [7]). Let $L_{2}(I, \rho)$ be the space of square integrable on $I$ with a positive measurable weight $\rho$ functions. In this space the question about discreteness of spectrum of the differential operator

$$
\mathcal{L} u=\frac{1}{\rho}\left(-\left(p u^{\prime}\right)^{\prime}+q u\right), x \in I=(a, b),
$$

is well studied. In the case $(a, b)=(-\infty, \infty)$, for the operator $-u^{\prime \prime}+q u$ a simple sufficient condition $\lim _{x \rightarrow \infty} q(x)=+\infty$ was obtained by K. Friedrichs [3]. The following necessary and sufficient condition was obtained by A. M. Molchanov [1]:

$$
(\forall \delta>0) \lim _{x \rightarrow \infty} \int_{x}^{x+\delta} q(x) d x=+\infty .
$$

Note that Molchanov studied the $n$-dimensional space $R^{n}$. The condition (1.3) is a special particular case for $n=1$. In the case $q=0$ for the operator $-(1 / \rho)\left(p u^{\prime}\right)^{\prime}$ a necessary 
and sufficient condition is obtained by I. Kac and M.G. Krein [2]. M. Birman [6] obtained a necessary and sufficient condition for an operator of even order on semiaxis $[0, \infty)$. Under condition $\int_{0}^{\infty} \rho(x) d x<\infty$ for the operator

$$
\mathcal{L}_{0} u=-(1 / \rho) u^{\prime \prime}
$$

the Birman's condition has the form

$$
\lim _{s \rightarrow \infty} s \int_{s}^{\infty} \rho(x) d x=0 .
$$

If $\int_{0}^{1} \rho(x) d x=\infty$, the condition

$$
\lim _{s \rightarrow 0} s \int_{s}^{\infty} \rho(x) d x=0
$$

together with (1.4) guaranties discreteness of spectrum of $-(1 / \rho) u^{\prime \prime}$. This second singularity is by cause of non-integrability of $\rho$ at the point $x=0$. This follows from the result of Kac and Krein [2] but it is not easy to see this at once.

Assume that the functions $\rho, p$ and $q$ are measurable, $\rho, p$ are positive in $I$, the function $q$ is non-negative. For almost all $x \in I$ the $r(x, \cdot)$ is a measure, that can be defined by a non-decreasing function $r(x, s)$. Assume that

$$
q(x) \geq r(x, I)
$$

almost everywhere on $I$. Assume that $1 / p$ and $\rho$ are locally integrable in $I$, that is

$$
\int_{s_{1}}^{s_{2}} \frac{d x}{p(x)}<\infty, \int_{s_{1}}^{s_{2}} \rho(x) d x<\infty,\left(a<s_{1}<s_{2}<b\right) .
$$

Say that $\mathcal{L}$ has singularity at $x=a$ by $p(x)$ if

$$
\int_{a}^{s} \frac{d x}{p(x)}=\infty, a<s<b .
$$

Analogously we mean singularities by $\rho$ and at $x=b$ (4 cases). It is clear that the singularity at the right end of the interval can be considered similarly to the left. Moreover, the singularity at the right end can be reduced to the singularity at the left end by the change of variable $x=-x^{\prime}$. Thus, we can consider some singularity only at the left end of $I$.

$$
\int_{s}^{b} \frac{d x}{p(x)}<\infty \text { and } \int_{s}^{b} \rho(x) d x<\infty \quad(a<s<b) .
$$

Only one type of singularity is allowed. We have to consider two cases: the first is

$$
\int_{a}^{s} \rho(x) d x=\infty, \int_{a}^{s} \frac{d x}{p(x)}<\infty
$$

and the second is

for any $s \in I$. Let

$$
\int_{a}^{s} \frac{d x}{p(x)}=\infty, \int_{a}^{s} \rho(x) d x<\infty
$$

$$
\Phi_{1}(s)=\int_{a}^{s} \frac{d x}{p(x)} \int_{s}^{l} \rho(x) d x, \quad \Phi_{2}(s)=\int_{a}^{s} \rho(x) d x \int_{s}^{l} \frac{d x}{p(x)}
$$


Theorem 1. Suppose one of the following conditions holds:

$$
\lim _{s \rightarrow 0} \Phi_{1}(s)=0 \text { or } \lim _{s \rightarrow 0} \Phi_{2}(s)=0 .
$$

Then the spectrum of the operator $\mathcal{L}$ is discrete. These conditions are necessary if for example the function $q(x)$ is bounded.

$\mathrm{R}$ e $\mathrm{m}$ a $\mathrm{r} \mathrm{k}$ 1. From this theorem it follows the sufficient discreteness condition in $[4,5]$.

\section{REFERENCES}

1. Molchanov A.M. Ob usloviyakh diskretnosti spektra dlya samosopryazhennykh uravneniy vtorogo poryadka [On conditions of discreteness of the spectrum for selfadjoint second order differential equations]. Trudy Moskovskogo matematicheskogo obshchestva [Proceedings of Moscow Mathematical Society], 1953, no. 2, pp. 169-199. Zbl 0052.10201. (In Russian).

2. Kats I., Kreyn M.G. Kriteriy diskretnosti spektra singulyarnoy struny [Criteria for the discreteness of the spectrum of a singular string]. Izvestiya vysshikh uchebnykh zavedeniy. Matematika [Bulletin of Higher Education Institutions. Mathematics], 1958, vol. 3, no. 2, pp. 136-153. Zbl 0272.34094, MR139804 34.30. (In Russian).

3. Friedrichs K. Spektraltheorie halbbeschr ankter operatoren und anwendung auf die spektralzerlegung von differentialoperatoren. Math. Ann., 1934, no. 109, pp. 465-487, 687-713. Zbl 0008.39203 \& Zbl 0009.07205, MR1512905 \& MR1512919.

4. Labovskiy S. On the Sturm-Liouville problem for a linear singular functional-differential equation. Russ. Math., 1996, vol. 40, no. 11, pp. 50-56. (English. Russian original. Translation from Iz Vyssh. Uchebn. Zaved., Mat., 1996, vol. 11, no. 414, pp. 48-53). Zbl 0909.34070, MR1442139 (97m:34120).

5. Labovskiy S. On spectral problem and positive solutions of a linear singular functionaldifferential equation. Functional Differential Equations, 2013, vol. 20, no. 3-4, pp. 179-200.

6. Birman M.Sh. O spektre singulyarnykh kraevykh zadach [On the spectrum of singular boundary-value problems]. Matematicheskiy sbornik [Sbornik: Mathematics], 1961, vol. 55, no. 2, pp. 125174. Zbl 0104.32601, MR142896. (In Russian).

7. Birman M.S., Solomjak M.Z. Spectral Theory of Self-Adjoint Operators in Hilbert Space. Holland, D. Reidel Publishing Company, 1987. Zbl 0744.47017.

Received 18 January 2018

Reviewed 06 February 2018

Accepted for press 20 February 2018

Labovskiy Sergey Mikhailovich, Plekhanov Russian University of Economics, Moscow, the Russian Federation, Candidate of Physics and Mathematics, Associate Professor of the Higher Mathematics Department, e-mail: labovski@gmail.com

For citation: Labovskiy S.M. O discretnosti spectra funkcionalno-differencialnogo operatora vtorogo poryadka [On discreteness of spectrum of a second order functional differential operator]. Vestnik Tambovskogo universiteta. Seriya Estestvennye $i$ tekhnicheskie nauki - Tambov University Reports. Series: Natural and Technical Sciences, 2018, vol. 23, no. 121, pp. 5-9. DOI: 10.20310/1810-0198-2018-23-121-5-9 (In Russian, Abstr. in Engl.). 


\title{
О ДИСКРЕТНОСТИ СПЕКТРА ФУНКЦИОНАЛЬНО-ДИФФЕРЕНЦИАЛЬНОГО ОПЕРАТОРА ВТОРОГО ПОРЯДКА
}

\author{
(c) С. М. Лабовский \\ ФГБОУ ВО «Российский экономический университет им. Г.В. Плеханова» \\ 117997, Российская Федерация, г. Москва, Стремянный пер., 36 \\ E-mail: labovski@gmail.com
}

Аннотация. Получены необходимые и достаточные условия дискретности спектра для сингулярного дифференциального оператора вида

$$
\frac{1}{\rho(x)}\left(-\left(p(x) u^{\prime}\right)^{\prime}+\int_{a}^{b} u(s) r(x, d s)\right), x \in(a, b),-\infty \leq a<b \leq \infty .
$$

Ключевые слова: дискретность спектра; функционально-дифференциальный оператор

\section{СПИСОК ЛИТЕРАТУРЫ}

1. Молчанов А.М. Об условиях дискретности спектра для самосопряженных уравнений второго порядка // Труды Московского математического общества. 1953. № 2. С. 169-199. Zbl 0052.10201.

2. Кач, И., Крейн М.Г. Критерий дискретности спектра сингулярной струны // Известия высших учебных заведений. Математика. 1958. Т. 3. № 2. С. 136-153. Zbl 0272.34094, MR139804 34.30 .

3. Friedrichs $K$. Spektraltheorie halbbeschränkter operatoren und anwendung auf die spektralzerlegung von differentialoperatoren // Math. Ann. 1934. № 109. P. 465-487, 687-713. Zbl 0008.39203 \& Zbl 0009.07205, MR1512905 \& MR1512919.

4. Labovskic $S$. On the Sturm-Liouville problem for a linear singular functional-differential equation // Russ. Math. 1996. Vol. 40. № 11. P. 50-56. (English. Russian original. Translation from Iz Vyssh. Uchebn. Zaved., Mat., 1996, vol. 11, no. 414, pp. 48-53). Zbl 0909.34070, MR1442139 (97m:34120).

5. Labovskiy S. On spectral problem and positive solutions of a linear singular functionaldifferential equation // Functional Differential Equations. 2013. Vol. 20. № 3-4. P. 179-200.

6. Бирман М.Ш. О спектре сингулярных краевых задач // Мат. сб. 1961. Т. 55. № 2. С. 125174. Zbl 0104.32601, MR142896.

7. Birman M.S. and Solomjak M.Z. Spectral Theory of Self-Adjoint Operators in Hilbert Space. Holland: D. Reidel Publishing Company, 1987. Zbl 0744.47017. 
Поступила в редакцию 18 января 2018 г.

Прошла рецензирование 06 февраля 2018 г.

Принята в печать 20 февраля 2018 г.

Лабовский Сергей Михайлович, Российский экономический университет им. Г.В. Плеханова, г. Москва, Российская Федерация, кандидат физико-математических наук, доцент кафедры высшей математики, e-mail: labovski@gmail.com

Для цитирования: Лабовский C.M. О дискретности спектра функционально-дифференциального оператора второго порядка // Вестник Тамбовского университета. Серия Естественные и технические науки. Тамбов, 2018. Т. 23. № 121. C. 5-9. DOI: 10.20310/1810-0198-2018-23-121-5-9 